\title{
Biogeochemical constraints on the origin of methane in an alluvial aquifer: evidence for the upward migration of methane from underlying coal measures
}

\author{
Charlotte P. Iverach ${ }^{1,2}$, Sabrina Beckmann ${ }^{3}$, Dioni I. Cendón ${ }^{1,2}$, Mike Manefield ${ }^{3}$, and Bryce F. J. Kelly ${ }^{1}$ \\ ${ }^{1}$ Connected Waters Initiative Research Centre, UNSW Australia, UNSW Sydney, NSW, 2052, Australia \\ ${ }^{2}$ Australian Nuclear Science and Technology Organisation, New Illawarra Rd, Lucas Heights, NSW, 2234, Australia \\ ${ }^{3}$ School of Biotechnology and Biomolecular Sciences, UNSW Australia, UNSW Sydney, NSW, 2052, Australia
}

Correspondence to: Charlotte P. Iverach (c.iverach@unsw.edu.au)

Received: 26 August 2016 - Published in Biogeosciences Discuss.: 5 September 2016

Revised: 12 December 2016 - Accepted: 24 December 2016 - Published: 17 January 2017

\begin{abstract}
Geochemical and microbiological indicators of methane $\left(\mathrm{CH}_{4}\right)$ production, oxidation and migration processes in groundwater are important to understand when attributing sources of gas. The processes controlling the natural occurrence of $\mathrm{CH}_{4}$ in groundwater must be understood, especially when considering the potential impacts of the global expansion of coal seam gas (CSG) production on groundwater quality and quantity. We use geochemical and microbiological data, along with measurements of $\mathrm{CH}_{4}$ isotopic composition $\left(\delta^{13} \mathrm{C}^{-} \mathrm{CH}_{4}\right)$, to determine the processes acting upon $\mathrm{CH}_{4}$ in a freshwater alluvial aquifer that directly overlies coal measures targeted for CSG production in Australia. Measurements of $\mathrm{CH}_{4}$ indicate that there is biogenic $\mathrm{CH}_{4}$ in the aquifer; however, microbial data indicate that there are no methanogenic archaea in the groundwater. In addition, geochemical data, particularly the isotopes of dissolved inorganic carbon (DIC) and dissolved organic carbon (DOC), as well as the concentration of $\mathrm{SO}_{4}^{2-}$, indicate limited potential for methanogenesis in situ. Microbial community analysis also shows that aerobic oxidation of $\mathrm{CH}_{4}$ occurs in the alluvial aquifer. The combination of microbiological and geochemical indicators suggests that the most likely source of $\mathrm{CH}_{4}$, where it was present in the freshwater aquifer, is the upward migration of $\mathrm{CH}_{4}$ from the underlying coal measures.
\end{abstract}

\section{Introduction}

Interest in methane $\left(\mathrm{CH}_{4}\right)$ production and degradation processes in groundwater is driven by the global expansion of unconventional-gas production. There is concern regarding the potential impacts of gas and fluid movement, as well as depressurisation, on groundwater quality and quantity in adjacent aquifers used to support other industries (Atkins et al., 2015; Heilweil et al., 2015; Iverach et al., 2015; Moritz et al., 2015; Owen et al., 2016; Zhang and Soeder, 2016).

In groundwater, $\mathrm{CH}_{4}$ can originate from numerous sources (Barker and Fritz, 1981). The two main sources of $\mathrm{CH}_{4}$ in shallow groundwater are in situ biological production (biogenic) and upward migration of $\mathrm{CH}_{4}$ from deeper geological formations (thermogenic to mixed thermo-biogenic to biogenic) (Barker and Fritz, 1981; Whiticar, 1999). This upward migration is via natural pathways such as geological faults and fracture networks (Ward and Kelly, 2007); however, it can also be induced via poorly installed wells and faulty well casings (Barker and Fritz, 1981; Fontenot et al., 2013). The main focus of the debate about the occurrence of $\mathrm{CH}_{4}$ in groundwater is whether it is naturally occurring or has been introduced by human activities. This research tests the hypothesis that a combination of geochemical indicators and microbiological data can inform production, degradation and migration processes of $\mathrm{CH}_{4}$ in the Condamine River alluvial aquifer (CRAA) in Australia. This freshwater aquifer directly overlies the Walloon Coal Measures (WCM), the target coal measures for coal seam gas (CSG) production in the study area. Thus, our study has ramifications for global 
unconventional-gas studies that investigate connectivity issues of freshwater aquifers.

Methane is subject to many production and degradation processes in groundwater (Whiticar, 1999). The carbon isotopic composition of $\mathrm{CH}_{4}\left(\delta^{13} \mathrm{C}^{-\mathrm{CH}_{4}}\right)$ gives insight into the source (Quay et al., 1999), but oxidation processes may enrich or deplete this signature (Yoshinaga et al., 2014). Therefore, it is very difficult to determine the potential source of $\mathrm{CH}_{4}$ and processes occurring using $\mathrm{CH}_{4}$ concentration and isotopic data alone.

Previous studies have used geochemical indicators, such as the concentration of sulfate $\left[\mathrm{SO}_{4}^{2-}\right]$, nitrate $\left[\mathrm{NO}_{3}^{-}\right]$and nitrite $\left[\mathrm{NO}_{2}^{-}\right]$, and the carbon isotopic composition of dissolved inorganic carbon $\left(\delta^{13} \mathrm{C}\right.$-DIC) and dissolved organic carbon $\left(\delta^{13} \mathrm{C}\right.$-DOC) to attribute the source of $\mathrm{CH}_{4}$ in groundwater (Valentine and Reeburgh, 2000; Kotelnikova, 2002; Antler, 2014; Green-Saxena et al., 2014; Antler et al., 2015; Hu et al., 2015; Segarra et al., 2015; Sela-Adler et al., 2015; Currell et al., 2016). Other studies have shown that the presence of active methanogenesis can be determined using isotopes of hydrogen in the $\mathrm{CH}_{4}\left(\delta^{2} \mathrm{H}-\mathrm{CH}_{4}\right)$ and the surrounding formation water $\left(\delta^{2} \mathrm{H}-\mathrm{H}_{2} \mathrm{O}\right)$ (Schoell, 1980; Whiticar and Faber, 1986; Whiticar, 1999; Currell et al., 2016). Additionally, recent studies have used clumped isotopes of $\mathrm{CH}_{4}$ and their temperature interpretations to ascribe a thermogenic versus biogenic source in groundwater (Stolper et al., 2014). However, non-equilibrium (kinetic) processes may be responsible for an overestimation of $\mathrm{CH}_{4}$ formation temperatures (Wang et al., 2015). Microbiological indicators (in addition to geochemical data) may resolve some of the uncertainties associated with the determination of $\mathrm{CH}_{4}$ origin, as they directly discriminate between microbiological communities involved in either production or degradation processes. There are no studies using combined geochemical and microbiological indicators to assess $\mathrm{CH}_{4}$ production and degradation processes in a freshwater aquifer. We aim to fill this gap in the literature.

Throughout the world the occurrence of freshwater aquifers adjacent to unconventional-gas production is common (Osborn et al., 2011; Moore, 2012; Roy and Ryan, 2013; Vidic et al., 2013; Vengosh et al., 2014; Moritz et al., 2015). We have previously shown that there may be local natural connectivity between the WCM and the CRAA (Iverach et al., 2015). Here we show that a combination of geochemical data $\left(\left[\mathrm{CH}_{4}\right],\left[\mathrm{SO}_{4}^{2-}\right],\left[\mathrm{NO}_{3}^{-}\right],\left[\mathrm{NO}_{2}^{-}\right], \delta^{13} \mathrm{C}_{-} \mathrm{CH}_{4}, \delta^{13} \mathrm{C}-\right.$ DIC, $\delta^{13} \mathrm{C}$-DOC and $\delta^{2} \mathrm{H}-\mathrm{H}_{2} \mathrm{O}$ ), as well as characterisation of microbiological communities present, can inform the discussion surrounding the occurrence of $\mathrm{CH}_{4}$ and its potential for upward migration in the groundwater of the CRAA.

\subsection{Geochemical indicators of methanogenic processes}

Methanogenesis via acetate fermentation (Eq. 1) and carbonate reduction (Eq. 2) can be restricted in groundwater with abundant dissolved $\mathrm{SO}_{4}^{2-}\left(>19 \mathrm{mg} \mathrm{L}^{-1}\right)$ (Whiticar, 1999) because sulfate-reducing bacteria (SRB) often outcompete methanogenic archaea for reducing equivalents (Lovley and Klug, 1985; Struchtemever et al., 2005).

$$
\begin{aligned}
& \mathrm{CH}_{3} \mathrm{COOH} \rightarrow \mathrm{CH}_{4}+\mathrm{CO}_{2} \\
& \mathrm{CO}_{2}+8 \mathrm{H}^{+}+8 e^{-} \rightarrow \mathrm{CH}_{4}+2 \mathrm{H}_{2} \mathrm{O}
\end{aligned}
$$

Therefore, the presence or absence of $\left[\mathrm{CH}_{4}\right]$ and $\left[\mathrm{SO}_{4}^{2-}\right]$ are good preliminary indicators of the potential for in situ methanogenesis.

In addition, the $\delta^{13} \mathrm{C}_{-} \mathrm{CH}_{4}$ of the underlying WCM in and around the study area has been characterised. Draper and Boreham (2006) characterised the isotopic signature of the WCM to be between -57.3 and $-54.2 \%$. Hamilton et al. (2014) and Baublys et al. (2015) expanded this range to be from -58.5 to -45.3 and -57 to $-44.5 \%$, respectively. Recently, Owen et al. (2016) have established a "shallow" WCM directly underlying the alluvium and a deeper "gas reservoir". The isotopic signatures of these range from -80 to -65 and -58 to $-49 \%$, respectively. These values are summarised in Table 1, along with available ranges of $\delta^{13} \mathrm{C}_{\text {DIC }}$ for the study area. Thus, the isotopic signature can be used to identify the potential source of the $\mathrm{CH}_{4}$; however, localised formation and oxidation processes that may occur either in the aquifer or during transport can confound the interpretation of mixing versus oxidation processes.

The isotopic compositions of DIC and DOC are also useful indicators of $\mathrm{CH}_{4}$ processes, as they can be used to determine the occurrence of methanogenesis (Kotelnikova, 2002; Wimmer et al., 2013). Kotelnikova (2002) found that ${ }^{13} \mathrm{C}$ depletion of $\delta^{13} \mathrm{C}$-DOC in combination with a ${ }^{13} \mathrm{C}$ enrichment of $\delta^{13} \mathrm{C}$-DIC was characteristic of methanogenesis in groundwater, consistent with the reduction of ${ }^{12} \mathrm{CO}_{2}$ by autotrophic methanogens. Conversely, $\delta^{13} \mathrm{C}$-DIC data are useful because DIC produced during $\mathrm{CH}_{4}$ oxidation was found to have a characteristically ${ }^{13} \mathrm{C}$-depleted signature (as depleted as $-50 \%$ ) (Yoshinaga et al., 2014; Hu et al., 2015; Segarra et al., 2015).

\subsection{Methane oxidation in freshwater}

In groundwater, $\mathrm{CH}_{4}$ is oxidised by methane-oxidising bacteria (MOB; methanotrophs) that can utilise $\mathrm{CH}_{4}$ as their sole carbon and energy source. These methanotrophs are grouped within the Alpha- and Gammaproteobacteria (comprising type-I and type-II methanotrophs) and the Verrucomicrobia (Hanson and Hanson, 1996). The first step of aerobic $\mathrm{CH}_{4}$ oxidation is the conversion of $\mathrm{CH}_{4}$ to methanol. This is catalysed by the particulate $\mathrm{CH}_{4}$ monooxygenase (pMMO) encoded by the $p m o A$ gene, which is highly conserved and used as a functional marker (Hakemian and Rosenzweig, 2007; McDonald et al., 2008). All known methanotrophs contain the pmoA gene, with members of Methylocella the exception (Dedysh et al., 2000; Dunfield et al., 2003). Type-II methanotrophs and some type-I members of the genus Methylococcus contain the mmoX gene, which encodes a soluble $\mathrm{CH}_{4}$ 
Table 1. Observed ranges of $\delta^{13} \mathrm{C}_{\mathrm{CH}_{4}}$ and $\delta^{13} \mathrm{C}_{\mathrm{DIC}}$ for the WCM in previous studies.

\begin{tabular}{|c|c|c|c|c|}
\hline Location of samples & $\delta^{13} \mathrm{C}_{\mathrm{CH}_{4}}$ range & $\delta^{13} \mathrm{C}_{\mathrm{CH}_{4}}$ median & $\delta^{13} \mathrm{C}_{\mathrm{DIC}}$ & Source \\
\hline WCM Surat Basin & -57.3 to $-54.2 \%$ & nd & nd & Draper and Boreham (2006) \\
\hline WCM - upper and lower measures & -58.5 to $-45.3 \%$ o & $-51.8 \%$ o & nd & Hamilton et al. (2014) \\
\hline WCM - upper and lower measures & -57.0 to $-44.5 \%$ & $-52.1 \%$ & $14.2 \%$ (median) & Baublys et al. (2015) \\
\hline WCM gas reservoir & -58.0 to $-49.0 \%$ & $-51.6 \%$ & 9.0 to $23.0 \%$ & Owen et al. (2016) \\
\hline WCM shallow & -80.0 to $-65.0 \%$ & $-75.0 \%$ & -15.9 to $-3.5 \%$ & Owen et al. (2016) \\
\hline
\end{tabular}

monooxygenase (sMMO) (McDonald et al., 1995; Murrell et al., 2000). Recently, new groups of aerobic and anaerobic MOB distantly related to known methanotrophic groups have been discovered (Raghoebarsing et al., 2006; Stoecker et al., 2006; Op den Camp et al., 2009). Geochemically, the expression of the pmoA and mmoX is triggered by the amount of available $\mathrm{Cu}$ ions. In addition, aerobic $\mathrm{CH}_{4}$ oxidation has been previously coupled to denitrification in groundwater (Zhu et al., 2016).

Besides methanotrophic bacteria, anaerobic $\mathrm{CH}_{4}$ oxidising archaea (ANME) also play a significant role in the oxidation of $\mathrm{CH}_{4}$ in both freshwater and saline water sources (Knittel and Boetius, 2009). These anaerobic methanotrophs are associated with the methanogenic Euryarchaeota within the clusters ANME-1, ANME-2 and ANME-3 and are closely related to the orders Methanosarcinales and Methanomicrobiales (Knittel et al., 2003, 2005). Geochemical indicators can provide evidence for the occurrence of AOM (anaerobic oxidation of methane), such as the prevalence of certain electron acceptors $\left(\mathrm{SO}_{4}^{2-}, \mathrm{NO}_{3}^{-}, \mathrm{NO}_{2}^{-}\right.$and $\left.\mathrm{Fe}^{2+}\right)$ (Valentine and Reeburgh, 2000; Ettwig et al., 2010; Sivan et al., 2011; Antler, 2014; Green-Saxena et al., 2014) and denitrification processes occurring in the groundwater (Ettwig et al., 2008; á Norði and Thamdrup, 2014; Timmers et al., 2015).

\section{Study area}

The CRAA is the primary aquifer in the Condamine Catchment (Fig. 1). It is used for irrigated agriculture, stock and domestic water supplies. There has been increased interest in the presence of $\mathrm{CH}_{4}$ in the aquifer due to expanding CSG production to the north-west of the study area (Fig. 1). CSG production began in 2006 (Arrow Energy, 2015) and has been expanding in the decade since then. This has raised concerns regarding the quality (especially with respect to $\mathrm{CH}_{4}$ concentrations) and quantity of the groundwater in the CRAA.

\section{Hydrogeological setting}

The CRAA sits within the Surat Basin, which sits within the Great Artesian Basin (GAB) in south-east Qld, Australia (Radke et al., 2000; Ransley and Smerdon, 2012) (Fig. 2).
Aquifers in the GAB vary between semi-confined and confined (Kelly and Merrick, 2007; Dafny and Silburn, 2014).

The environment of deposition for the Surat Basin was fluviolacustrine in the late Triassic-Jurassic and shallow marine and coastal in the Cretaceous (Hamilton et al., 2012). The middle-Jurassic WCM are a group of low-rank coal seams in the Surat Basin targeted for CSG production (Hamilton et al., 2012). The WCM are thicker (150 to $350 \mathrm{~m}$ ) along the western margin of the CRAA and thin to around $50 \mathrm{~m}$ in the east, where the unit outcrops (KCB, 2011); however, only around $10 \%$ of this is coal. The unit consists of very fineto medium-grained sandstone, siltstone, mudstone and coal, with minor calcareous sandstone, impure limestone and ironstone (KCB, 2011). The coal consists of numerous discontinuous thin lenses separated by sediments of low permeability (Hillier, 2010). The unit dips gently to the west (around $4^{\circ}$ ), which is consistent with the general trend of the Surat Basin in this region.

The WCM overlie the Eurombah Formation (consisting of conglomerate sandstone with minor siltstones and mudstone beds) and underlie the Kumbarilla Beds (mainly sandstone, with lesser mudstone, siltstones and conglomerates) (KCB, 2011).

The unconfined CRAA fills a paleovalley that was carved through the GAB (including the WCM). The valley-filling sediments are composed of gravels and fine- to coursegrained channel sands interbedded with floodplain clays and, on the margins, colluvial deposits, which were deposited from the mid-Miocene to the present (Huxley, 1982; Kelly and Merrick, 2007; Dafny and Silburn, 2014). The valleyfilling sediments have a maximum thickness of $134 \mathrm{~m}$ near Dalby (Dafny and Silburn, 2014). Along the eastern margin of the valley, the CRAA is bounded by the Main Range Volcanics. Estimations of the sources and quantity of recharge to the CRAA vary widely; however, streambed recharge is generally considered to be the major source of freshwater to the aquifer (Dafny and Silburn, 2014).

A low-permeability layer (ranging from $8 \times 10^{-6}$ to $1.5 \times$ $10^{-1} \mathrm{~m} \mathrm{day}^{-1}$ ) has been reported between the CRAA and the underlying WCM (KCB, 2011; QWC, 2012). This has been referred to as the "transition layer" (QWC, 2012) or a "hydraulic basement" to the alluvium (KCB, 2011). The thickness of this layer varies between $30 \mathrm{~m}$ in some areas to completely absent in others. Thus, in some places the WCM 


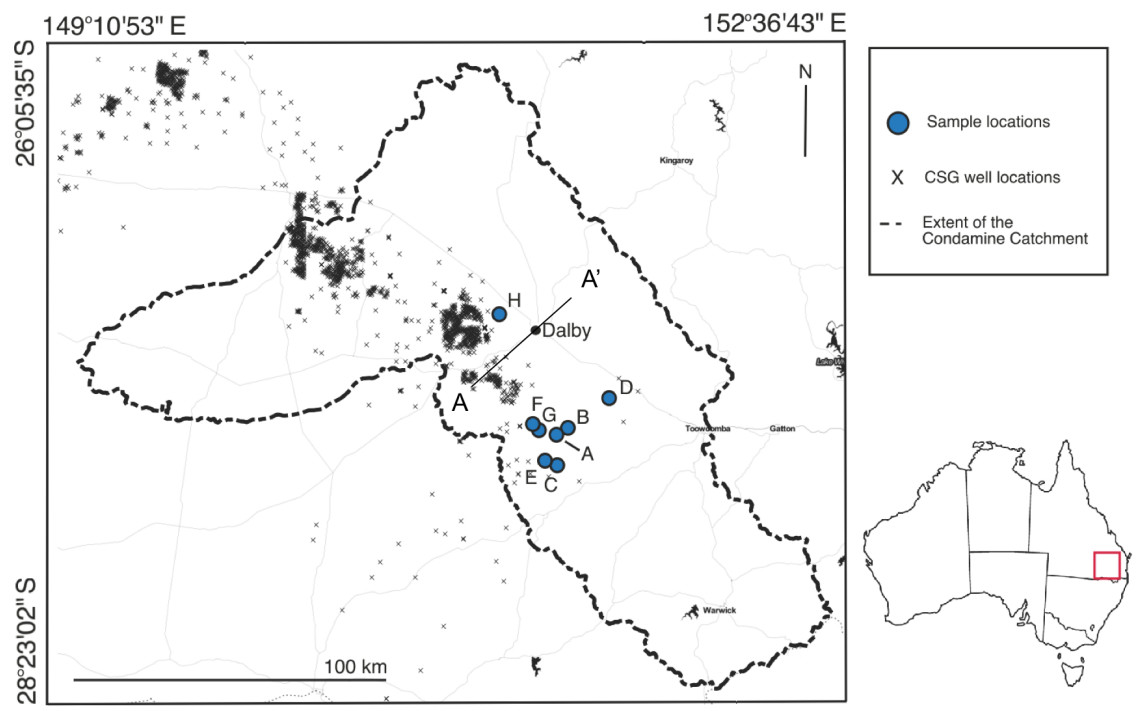

Figure 1. Site map showing the extent of the study area and sample locations within the Condamine Catchment, south-east Queensland, Australia. Map created in QGIS; data and imagery: Statem Toner, Open Street Map and contributors, CC-BY-SA (QGIS 2.8.2 Wien, 2015). Modified with Corel Painter 2015 (Corel Corporation, 2015).

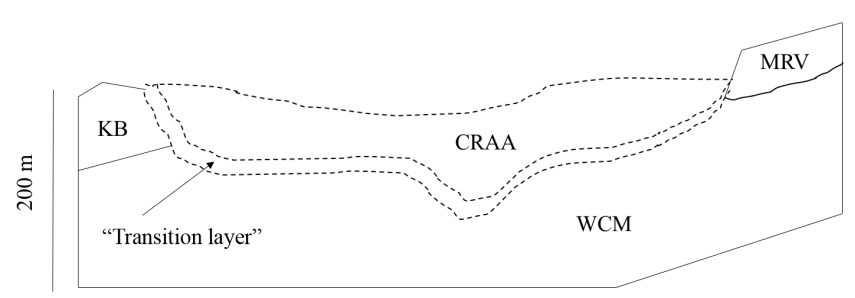

Figure 2. Geological cross section along $\mathrm{A}-\mathrm{A}^{\prime}$ in Fig. 1 (adapted from Dafny and Silburn, 2014). KB - Kumbarilla Beds; MRV Main Range Volcanics.

immediately underlies the CRAA (Dafny and Silburn, 2014). This suggests that there is some level of connectivity between the CRAA and the WCM. Huxley (1982) and Hillier (2010) both suggest that the general decline in water quality downstream is due to net flow of the more saline WCM water into the CRAA. Connectivity between the formations is not well understood; however, studies have been conducted to better understand the movement of both water and gas between the two aquifers. Duvert et al. (2015) and Owen and Cox (2015) both used hydrogeochemical analyses to show that there was limited movement of water between the two formations. By contrast, Iverach et al. (2015) used the isotopic signature of $\mathrm{CH}_{4}$ in the groundwater to show that there was localised movement of gas between the coal measures and the overlying aquifer.

More recently, a report prepared by the Office of Groundwater Impact Assessment, Department of Natural Resources and Mines, found that a low-permeability transition layer ex- ists between the CRAA and the zones of the WCM that could contain commercially viable CSG. The report concluded that, overall, the level of hydraulic connectivity between the CRAA and the WCM is low (OGIA, 2016). This research provides additional insight to inform the debate about the degree of connectivity for both water and gas between the WCM and the CRAA. The microbiological insights also inform the global research on biological $\mathrm{CH}_{4}$ production and degradation in alluvial aquifers, in particular for zones distal to the river corridor.

\section{Methods}

From 22 to 31 January 2014 we collected groundwater samples for geochemical analysis from eight private irrigation boreholes in the Condamine Catchment (locations shown in Fig. 1). Iverach et al. (2015) outlines the complete methods for sample collection for $\left[\mathrm{CH}_{4}\right]$ and $\delta^{13} \mathrm{C}_{-} \mathrm{CH}_{4}$ and subsequent analysis. The eight samples collected from the unconfined CRAA are representative of the aquifer, given their varied depths and locations (Table 2).

Groundwater samples were collected by installing a sampling tube $2 \mathrm{~m}$ inside the pump outlet of the borehole to avoid the air-water interface at the sampling point. Field parameters (electrical conductivity (EC), oxidation-reduction potential (ORP), dissolved oxygen (DO), temperature $(T)$ and $\mathrm{pH}$ ) were monitored in a flow cell to ensure stabilisation before samples were collected. The boreholes had been pumping continuously over the preceding month for irrigation, and so stabilisation of the field parameters was reached within minutes. Groundwater samples for the analysis of major anions and water-stable isotopes $\left(\delta^{2} \mathrm{H}-\mathrm{H}_{2} \mathrm{O}\right.$ and $\left.\delta^{18} \mathrm{O}-\mathrm{H}_{2} \mathrm{O}\right)$ were 
Table 2. Slotted depth intervals for the 8 samples.

\begin{tabular}{lr}
\hline Sample & Depth interval $(\mathrm{m})$ \\
\hline A & $46.6-60.3$ \\
B & $64.9-69.5$ \\
C & $33.9-41.8$ \\
D & $19.5-35.7$ \\
E & $23.6-42.5$ \\
F & $28.6-40.8$ \\
G & $31.7-35.4$ \\
H & $25.3-50.3$ \\
\hline
\end{tabular}

collected after passing the water through a $0.45 \mu \mathrm{m}$, highvolume groundwater filter, which was connected to the pump outlet. Samples for the analysis of anions and water stableisotopes were stored in $125 \mathrm{~mL}$ high-density polyethylene (HDPE) bottles and $30 \mathrm{~mL}$ HDPE bottles, respectively. Both had no further treatment. The water for $\delta^{13} \mathrm{C}$-DIC and $\delta^{13} \mathrm{C}$ DOC was further filtered through a $0.22 \mu \mathrm{m}$ filter and stored in $12 \mathrm{~mL}$ Exetainer vials and $60 \mathrm{~mL}$ HDPE bottles, respectively. Samples to be analysed for DIC were refrigerated at $4{ }^{\circ} \mathrm{C}$ and analysed within 1 month. Samples to be analysed for DOC were frozen within $12 \mathrm{~h}$ of collection.

Groundwater samples for the microbiological analyses were collected between 8 and 11 December 2014 from the same eight private irrigation boreholes used for the geochemical analyses. Groundwater samples for microbiological analysis were collected in 2 L Duran Schott bottles and sealed (gas-tight). We used aspects of the geochemical data collected in the January campaign to interpret the microbial results from the December campaign.

\subsection{Geochemical analyses}

The major ion chemistry in the groundwater samples was analysed at the Australian Nuclear Science and Technology Organisation (ANSTO) using inductively coupled plasma atomic emission spectroscopy for cations and ion chromatography for anions. The samples for $\delta^{2} \mathrm{H}-\mathrm{H}_{2} \mathrm{O}$ and $\delta^{18} \mathrm{O}-\mathrm{H}_{2} \mathrm{O}$ were analysed at ANSTO and are reported as per mill deviations from the international standard V-SMOW (Vienna Standard Mean Ocean Water). $\delta^{18} \mathrm{O}$ samples were run using an established equilibration, continuous-flow IRMS (isotopic ratio mass spectrometry) method and $\delta^{2} \mathrm{H}$ samples were run using an online combustion, dual-inlet IRMS method (Cendón et al., 2015).

The isotopes of carbon in DIC were analysed at ANSTO using an established method on a Delta V Advantage mass spectrometer, and a GasBench II peripheral. The results are reported as a per mill deviation from IAEA secondary standards that have been certified relative to V-PDB (Vienna Pee Dee Belemnite) for carbon (Cendón et al., 2015). The isotopes of carbon in DOC were analysed at the UC-Davis (University of California, Davis) Stable Isotope Facility; results are reported as per mill and are corrected based on laboratory standards calibrated against NIST Standard Reference Materials with an analytical precision of $\pm 0.6 \%$. Samples were run using a total organic carbon (TOC) analyser connected to a PDZ Europa 20-20 IRMS using a GD-100 Gas Trap interface (Meredith et al., 2016). The $\left[\mathrm{SO}_{4}^{2-}\right]$ were too low in six of the eight samples for $\delta^{34} \mathrm{~S}$ and $\delta^{18} \mathrm{O}$ analysis. The remaining two samples were analysed for their sulfur and oxygen isotope compositions at the University of Calgary Isotope Science Laboratory. Sulfur isotope ratios were analysed using continuous-flow elemental analysis isotope ratio mass spectrometry (CF-EA-IRMS) with an elemental analyser interfaced to a VG PRISM II mass spectrometer (Cendón et al., 2015). The results are reported against V-CDT (Vienna Canyon Diablo Troilite). The oxygen isotope ratio was determined using a high temperature reactor coupled to an isotope ratio mass spectrometer in continuous-flow mode (Cendón et al., 2015).

\subsection{DNA extraction and Illumina sequencing}

DNA was extracted from the biomass collected from filtering $2 \mathrm{~L}$ of groundwater using a $0.2 \mu \mathrm{m}$ filter (Merck Millipore). Briefly, DNA was isolated using a phenol-chloroform extraction method as described by Lueders et al. (2004). The DNA was then precipitated using polyethylene glycol 6000 (Sigma Aldrich), and the DNA pellet was washed using $70 \%(v / v)$ ethanol and resuspended in $50 \mu \mathrm{L}$ nuclease free water (Qiagen). DNA concentration and purity were determined by standard agarose gel electrophoresis and fluorometrically using RiboGreen (Qubit Assay Kit, Invitrogen) according to the manufacturer's instructions. The extracted DNA was used as a target for Illumina sequencing. Amplicon libraries were generated by following Illumina's $16 \mathrm{~S}$ Metagenomic Sequencing Library Preparation Protocol, using $12.5 \mathrm{ng}$ of template DNA per reaction. The number of cycles for the initial PCR was reduced to 21 to avoid biases from over-amplification. The following universal primer pair was used for the initial amplification, consisting of an Illumina-specific overhang sequence and a locus-specific sequence:

926F_Illum(5'-TCGTCGGCAGCGTCAGATGTGTATA AGAGACAG[AAACTYAAAKGAATTGRCCG]-3'),

1392R_Illum(5'-GTCTCGTGGGCTCGGAGATGTGTA TAAGAGACAG[ACGGGCGGTGTGTRC]-3').

This universal primer pair targets the V6-V8 hypervariable regions of the $16 \mathrm{~S}$ ribosomal RNA gene and has been shown to capture the microbial diversity of Bacteria and Archaea in a single reaction (Wilkins et al., 2013). PCR products were purified using a magnetic bead capture kit (Agencourt AMPure XP (Beckman Coulter)) and quantified using a fluorometric kit (RiboGreen, Qubit Assay Kit, Invitrogen). Purified amplicons were subjected to the Index PCR using the MiSeq platform (Ramaciotti Centre for Genomics, UNSW Australia) according to the manufacturer's specifica- 
tions. Illumina sequences were checked for quality (FastQC, BaseSpace) and analysed using the BaseSpace cloud computing platform (Illumina, 2016) and mothur (Schloss, 2009) with modified protocols (Schloss et al., 2009; Kozich et al., 2013). Taxonomy was assigned according to the SILVA Database (SILVA, 2016). To ensure even sampling depth for subsequent analyses, OTU (operational taxonomic unit) abundance data were rarefied to the lowest number of sequences for a sample (8300 sequences per sample).

\subsection{Quantification of bacterial and archaeal 16S rRNA and functional genes}

Quantitative real-time PCR was used to determine abundances of bacterial and archaeal 16S rRNA gene targets and functional gene targets ( $m c r A, p m o A, m m o X$ and $d s r A$ ), using the MJ Mini ${ }^{\mathrm{TM}} 96$ Well Thermal Cycler (Bio-Rad, Hercules, CA). Each qPCR (quantitative real-time PCR) $25 \mu \mathrm{L}$ reaction mixture contained $12.5 \mu \mathrm{L}$ of premix solution from an iQ SYBRGreen qPCR Kit (Bio-Rad), $8 \mu \mathrm{L}$ PCR-grade water, $1.5 \mu \mathrm{L}$ of each primer (final concentration $0.2-0.5 \mu \mathrm{M})$ and $2 \mu \mathrm{L}$ of template DNA $(10 \mathrm{ng})$. Bacterial and archaeal 16S rRNA genes were amplified using the primer pairs 519F/907R (Lane, 1991; Muyzer et al., 1995) and SDArch0025F/SDArch0344R (Vetriani et al., 1999). $m c r A$ and $d s r A$ sequence fragments were amplified using the primer pairs ME1F/ME3R (Hales et al., 1996) and 1F/500R (Wagner et al., 1998; Dhillon et al., 2003). qPCR was performed as described previously by Wilms et al. (2007). pmoA qPCR was performed using the pmoA primer pair A189F (Holmes et al., 1999) and mb661R (Kolb et al., 2003) with a final total primer concentration of $0.8 \mu \mathrm{M}$. The qPCR programme for the amplification was as follows: $95^{\circ} \mathrm{C}$ for $3 \mathrm{~min}$ followed by 40 cycles of $95^{\circ} \mathrm{C}$ for $30 \mathrm{~s}, 64^{\circ} \mathrm{C}$ for $45 \mathrm{~s}$ and $68^{\circ} \mathrm{C}$ for $45 \mathrm{~s}$. The $m m o X$ gene fragment was quantified using the primer pairs mmoX-ms-945f and mmoXB-1401b at a final total concentration of $0.8 \mu \mathrm{M}$. The qPCR conditions for the $m m o X$ were as follows: $94^{\circ} \mathrm{C}$ for 3 min followed by 45 cycles of $94^{\circ} \mathrm{C}$ for $1 \mathrm{~min}, 50^{\circ} \mathrm{C}$ for $1 \mathrm{~min}$ and $72^{\circ} \mathrm{C}$ for $1 \mathrm{~min}$. Bacterial and archaeal targets were measured in at least three different dilutions of DNA extracts $(1: 10,1: 100$, $1: 1000)$ and in triplicate. To maintain inter-assay reliability, standards ranging from $10^{8}$ to $10^{2}$ copies $\mu \mathrm{L}^{-1}$ were included on each assay plate to account for slight variations between runs. A no-template control (NTC) of molecularbiology-grade $\mathrm{H}_{2} \mathrm{O}$ was also included on each plate to detect PCR contamination. PCR products were checked by gel electrophoresis using $2 \%(w / v)$ agarose with TBE buffer (90 mM Tris, $90 \mathrm{mM}$ boric acid, $2 \mathrm{mM} \mathrm{Na} 2$-EDTA; pH 8.0). The specificity of the reactions was confirmed by melting curve analysis and agarose gel electrophoresis to identify non-specific PCR products. Amplification efficiencies for all reactions ranged from 96.3 to $110.5 \%$ with an $r^{2}$ value of $>0.99$ for standard curve regression. DNA calibration standards for qPCR were prepared as follows. The mcrA, $d s r A$,
pmoA and $m m o X$ genes were amplified from pure cultures of Methanosarcina barkeri (DSM 800), Desulfovibrio vulgaris (DSM 644), Methylosinus sporium (DSM 17706) and Methylocella silvestris (DSM 15510; DSMZ, Brunswick, Germany). The PCR amplicons were purified using the DNA Clean and Concentrator ${ }^{\mathrm{TM}}-5$ kit (Zymo Research, Irvine, CA) and eluted into $20 \mu \mathrm{L}$ DNA elution buffer. DNA concentrations were quantified with $2 \mu \mathrm{L}$ DNA aliquots using the Qubit $^{\circledR}$ dsDNA BR Assay Kit (Invitrogen, Life Technologies, Carlsbad, CA). Purified target gene PCR products were cloned into plasmids following the manufacturer's instructions for the pGEM $^{\circledR}$ - T Easy Vector System (Promega, Madison, WI).

\section{Results and discussion}

\subsection{Previous $\delta^{13} \mathrm{C}-\mathrm{CH}_{4}$ investigation}

A previous study by Iverach et al. (2015) analysed the $\delta^{13} \mathrm{C}$ $\mathrm{CH}_{4}$ in the groundwater from an off-gassing port on the eight private irrigation boreholes studied here (samples A-H) (Table S3 in the Supplement). These measurements were understood to have been mixing with regional background atmospheric $\mathrm{CH}_{4}(1.774 \mathrm{ppm} ;-47 \%$ o); therefore, mixing plots were used to infer the isotopic source signature of the $\mathrm{CH}_{4}$ off-gassing from the groundwater. Iverach et al. (2015) found that samples $\mathrm{E}, \mathrm{G}$ and $\mathrm{H}$ plotted on a regression line that had an isotopic source signature of $-69.1 \%$ o $(90 \% \mathrm{CI},-73.2$ to $-65.0 \%$ ), indicative of a biological source. However, samples A, B, C, D and F plotted on a regression line that had an isotopic source signature of $-55.9 \%$ ( $90 \% \mathrm{CI},-58.3$ to $-53.4 \%$ ), suggesting either oxidation was occurring at the source or there was upward migration of $\mathrm{CH}_{4}$ from the underlying WCM.

\subsection{Limited geochemical and microbiological potential for methanogenesis in the groundwater}

To further elucidate the source of the $\mathrm{CH}_{4}$ reported in the groundwater (Iverach et al., 2015), Illumina sequencing and quantitative real-time PCR were used to target bacterial and archaeal 16S rRNA genes, as well as specific functional genes ( $m c r A, p m o A, m m o X$ and $d s r A$ ) associated with $\mathrm{CH}_{4}$ metabolism. Microbial abundances estimated by SYBRGreen I counts were between $10^{3}$ and $10^{5}$ cells $\mathrm{mL}^{-1}$ throughout all groundwater samples (Fig. 3). This was congruent with the qPCR data observed for bacterial and archaeal cell concentrations.

The groundwater community was primarily composed of bacteria (79-90\%), whilst archaea made up 10-21\% (Fig. 4). The bacterial and archaeal community composition did not vary significantly between groundwater samples. Most of the bacterial sequences belonged to the phyla Proteobacteria $(\alpha-\delta)$, Acidobacteria, Actinobacteria, Firmicutes and the Bacteroidetes/Chlorobi group (Fig. 4). The 


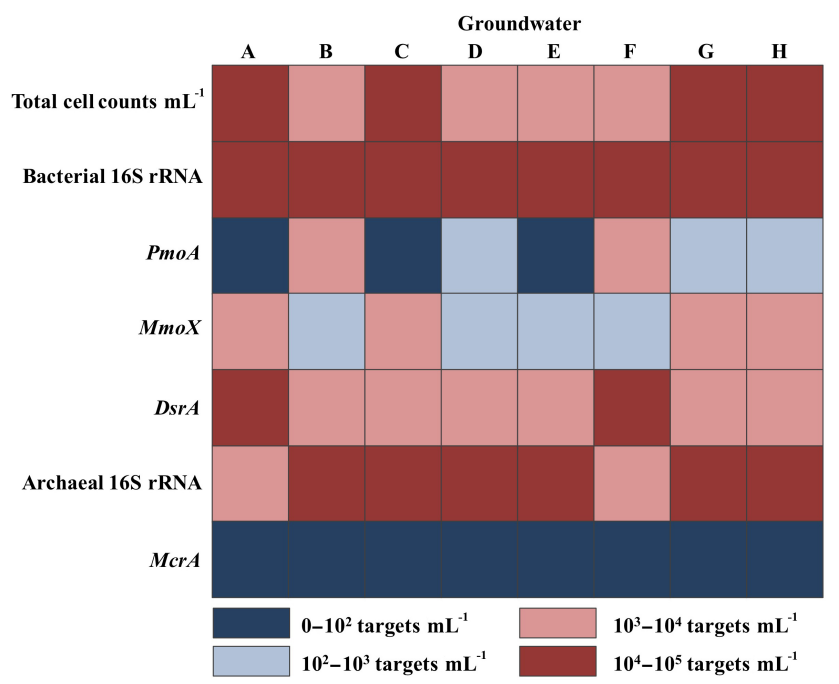

Figure 3. Total cell concentration and copy number abundances of bacterial and archaeal 16SrRNA genes and functional key genes for aerobic $\mathrm{CH}_{4}$ oxidation ( $p m o A$ and $\left.m m o X\right), \mathrm{CH}_{4}$ production (mcrA) and sulfate reduction $(d s r A)$ in the groundwater carried out by quantitative PCR. Low abundances are highlighted in dark blue. High abundances are highlighted in dark red. The calculated standard deviations for replicate quantifications of one sample were consistently between $10-20 \%$.

phylum Thaumarchaeota dominated the archaeal communities with a relative abundance of $81-99 \%$, while Crenarchaeota made up $1-3 \%$. Further sequences were related to other (if $<1 \%$ relative abundance) and unclassified Bacteria and Archaea. No members of the Euryarchaeota, comprising the methanogenic archaea, were observed. The archaeal $m c r A$ gene, which encodes the methyl coenzyme M reductase, was not detected in any of the groundwater samples (detection limit $<10$ cells $\mathrm{mL}^{-1}$; Fig. 3 ). This was consistent with the Illumina sequencing results and suggests that the $\mathrm{CH}_{4}$ observed off-gassing from the groundwater was not being produced in situ within the CRAA.

The microbial community in the groundwater was assumed to reflect that of the geological formations because when we sample the groundwater, we are also sampling fine particles with biomass attached. Additionally, Maamar et al. (2015) found that the microbial community composition of groundwater was controlled by groundwater residence times and flow paths, independent of the geology. Further, the intense purging of the production wells in the Condamine alluvium ensure that we are sampling groundwater that is representative of the sampled formations.

Our isotopic geochemical data also showed no evidence for the occurrence of methanogenesis in the groundwater. As previously stated, a ${ }^{13} \mathrm{C}$ enrichment in $\delta^{13} \mathrm{C}$-DIC coupled with a ${ }^{13} \mathrm{C}$ depletion in the $\delta^{13} \mathrm{C}$-DOC is characteristic of methanogenesis (Kotelnikova, 2002). Our groundwater data showed no correlation between $\delta^{13} \mathrm{C}$-DOC and $\delta^{13} \mathrm{C}$ -
DIC (Fig. 5a), and the most ${ }^{13} \mathrm{C}$-enriched $\delta^{13} \mathrm{C}$-DIC was also the second highest enriched $\delta^{13} \mathrm{C}$-DOC value. Additionally, on a stable water isotope plot (Fig. 5b; Table S1 in the Supplement), it is evident that there is no noticeable $\delta^{2} \mathrm{H}$ enrichment that can be ascribed to methanogenesis in any of the groundwater samples (Cendón et al., 2015).

These geochemical analyses, along with the lack of classified methanogens, suggest that biogenic $\mathrm{CH}_{4}$ production is not one of the major processes responsible for the presence of $\mathrm{CH}_{4}$ in the CRAA. Therefore, the $\mathrm{CH}_{4}$ reported in all samples in Iverach et al. (2015) must be derived from another source. We propose that the upward migration of $\mathrm{CH}_{4}$ from the WCM must be considered as the potential source. The isotopic signature of $\mathrm{CH}_{4}$ from the deeper coal measures has been characterised between -58.5 and $-45.3 \%$, indicating thermogenic $\mathrm{CH}_{4}$ with a secondary biogenic component (Papendick et al., 2011; Hamilton et al., 2012, 2014). Five of the eight samples analysed in this study have an isotopic source signature within this range, as reported in Iverach et al. (2015). This implies that upward migration from the deeper WCM is the source of the $\mathrm{CH}_{4}$ detected in the groundwater.

However, the remaining three samples (samples E, G and $\mathrm{H}$ ) have a typically biogenic isotopic source signature $(-69.1 \%)$. Owen et al. (2016) recently characterised the isotopic signature of both the WCM gas reservoir and the shallow WCM layer between the gas reservoir and the overlying alluvium (Table 1). The isotopic signature for the shallow WCM samples was between -80 and $-65 \%$. The three samples here, which exhibit a source signature of $-69.1 \%$, could potentially be sourcing $\mathrm{CH}_{4}$ from the shallow WCM. This would result in a biological source signature of the $\mathrm{CH}_{4}$ in the overlying aquifer despite the absence of methanogenic archaea.

\subsection{Sulfate reducers and aerobic methanotrophs potentially outcompete methanogens}

Sulfate concentrations in most groundwater samples were low (3.2-11 $\mathrm{m} \mathrm{L}^{-1}$ ) (Table S2 in the Supplement). Groundwater samples $\mathrm{D}$ and $\mathrm{H}$ were higher with 55 and $29 \mathrm{~m} \mathrm{~L}^{-1}$, respectively (Table S2 in the Supplement). Sequence and functional $d s r A$ gene analysis (encoding the dissimilatory sulfite reductase of SRB) revealed that SRB are present in all groundwater samples at relatively high abundances (5$10 \%$ of the overall microbial community; Figs. 3 and 4). These SRB are potentially outcompeting methanogenic archaea for substrates such as acetate and $\mathrm{H}_{2}$. Sulfate concentrations higher than $3 \mathrm{mg} \mathrm{L}^{-1}$, as detected in all groundwater samples $\left(3.2-55 \mathrm{mg} \mathrm{L}^{-1}\right)$, could potentially create a $\mathrm{SO}_{4}^{2-}$. reducing environment with the predominance of SRB over methanogens. This would potentially maintain the acetate at concentrations too low for methanogens to grow (Lovley and Klug, 1985). Deltaproteobacteria were dominant in all groundwater samples, and most of the sequences were 


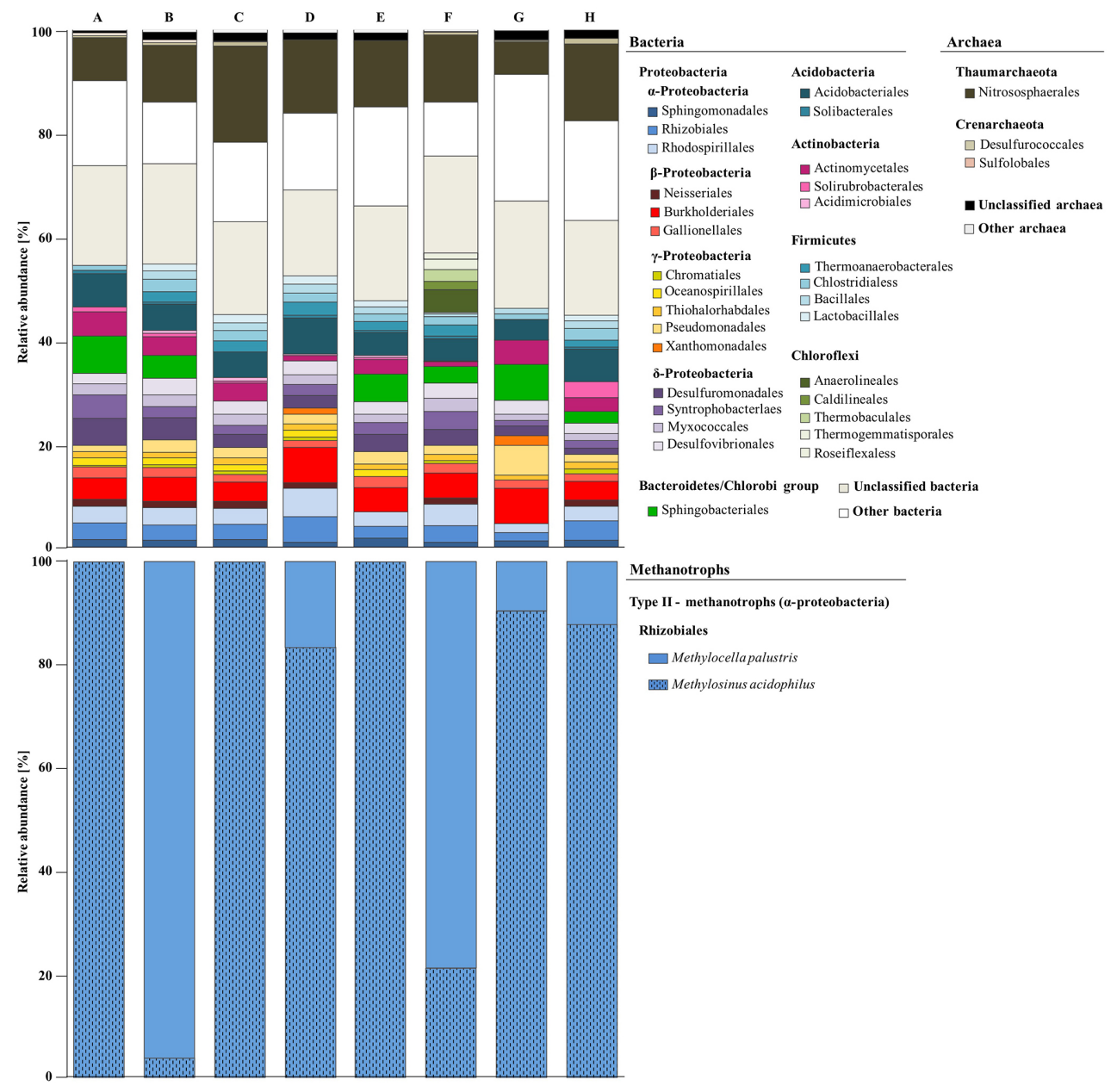

Figure 4. Bacterial, archaeal and methanotrophic community profiles and relative abundances detected by Illumina sequencing.

closely related to acetate-oxidising, sulfate/sulfur-reducing bacteria (Desulfovibrionales, Syntrophobacterales, Desulfuromonadales; Fig. 4). Additionally, Methylocella spp. are capable of using methanogenic substrates, such as acetate and methylamines, for their metabolism and therefore are not limited to growing on one-carbon compounds such as $\mathrm{CH}_{4}$ (Dedysh et al., 2005). This could have major implications for the lack of methanogenic activity in the groundwater. In addition, the presence of $\mathrm{SO}_{4}^{2-}$ along with conditions favouring SRB is further evidence that in situ methanogenesis is unlikely to be responsible for the presence of $\mathrm{CH}_{4}$ in the shallow aquifer.

\subsection{Microbial methane oxidation in the groundwater catalyses upward-migrating methane from the WCM}

The functional gene for aerobic $\mathrm{CH}_{4}$ oxidation (pmoA) was detected at relatively high concentrations $\left(7.9 \times 10^{2}-\right.$ $9.3 \times 10^{3}$ targets $\mathrm{mL}^{-1}$ ) compared to the overall bacterial $16 \mathrm{~S}$ rRNA concentration $\left(2.5 \times 10^{4}-5.1 \times 10^{4}\right.$ targets $\left.\mathrm{mL}^{-1}\right)$
(Fig. 3). All groundwater samples were characterised with regard to the community structure of MOB. The samples harboured a low-diversity methanotrophic community associated with the order Rhizobiales (Alphaproteobacteria); however, MOB accounted for up to $7 \%$ of the overall microbial community (Fig. 4). All groundwater samples were dominated by two MOB, belonging to the type-II methanotrophs (Fig. 4). Five samples had both Methylocella palustris (family Beijerinckiaceae) and Methylosinus acidophilus (family Methylocystaceae) (samples B, D, F-H), whilst the remaining samples comprised Methylosinus acidophilus only (samples A, C and E) (Fig. 4). These genera were characterised as aerobic $\mathrm{CH}_{4}$ oxidisers; however, aerobic MOB have been previously observed in microaerophilic and anaerobic environments (Bowman, 2000). This suggests the existence of an alternative pathway for aerobic $\mathrm{CH}_{4}$ oxidation in a suboxic/anaerobic environment. Both species have previously been found and isolated from a variety of freshwater habitats and Methylosinus spp. are known to be dominant methanotrophic populations in groundwater (Bowman, 

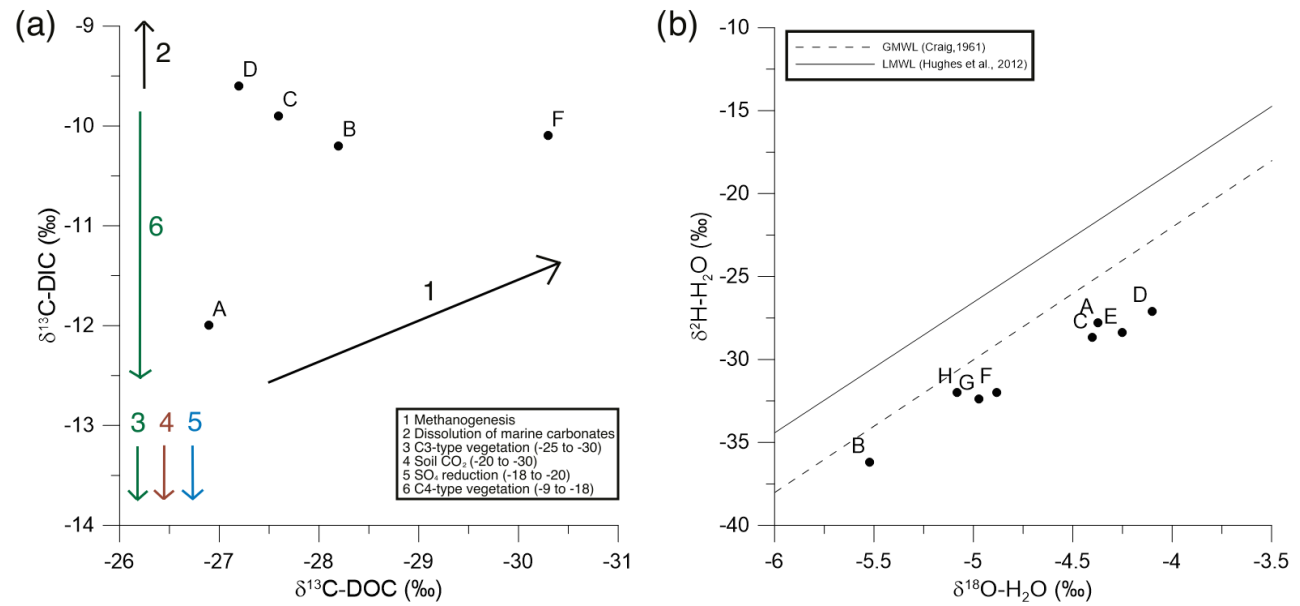

Figure 5. (a) A plot of $\delta^{13} \mathrm{C}$-DOC vs. $\delta^{13} \mathrm{C}$-DIC. There is no correlation between these geochemical data, indicating that there is no methanogenic end member in our samples. Samples E, G and H are omitted because they were below the detection limit for $\delta^{13} \mathrm{C}-\mathrm{DOC}$ (Table S1 in the Supplement). Arrow 1 delineates the expected trend for methanogenesis, and arrow 2 is the expected trend for the dissolution of marine carbonates (Currell et al., 2016). Arrows 3-6 highlight expected ranges for $\delta^{13} \mathrm{C}$-DIC that are off the scale of the graph (Currell et al., 2016). (b) A plot of $\delta^{18} \mathrm{O}-\mathrm{H}_{2} \mathrm{O}$ vs. $\delta^{2} \mathrm{H}-\mathrm{H}_{2} \mathrm{O}$ showing that there is no ${ }^{2} \mathrm{H}$ enrichment in any of the groundwater samples. The GMWL (global meteoric water line; Craig, 1961) and LMWL (local meteoric water line; Hughes and Crawford, 2012) are also displayed.

2000). Methylocella and Methylosinus spp. possess a soluble $\mathrm{CH}_{4}$ monooxygenase (mmoX) (McDonald et al., 1995; Murrell et al., 2000), which is consistent with the high abundance of the mmoX gene targeted in all groundwater samples (Fig. 3). Interestingly, no pmoA gene, a biomarker for all MOBs, has previously been detected in known Methylosinus spp. (Dedysh et al., 2005). This is supported by our data, which show the sole predominance of $m m o X$ genes in three of the eight groundwater samples that are exclusively dominated by Methylosinus sp. (samples A, C and E) (Figs. 2 and $3)$.

In addition to low concentrations of $\mathrm{CH}_{4}$ reported in Iverach et al. (2015), the dissolved $\mathrm{O}_{2}$ (DO) in our groundwater samples had a large range, from low to close to saturation (0.91 to $\left.8.6 \mathrm{mg} \mathrm{L}^{-1}\right)$. The reported concentration of DO for the groundwater was measured at the ground surface and is therefore not an accurate measure of the in situ value. However, it could contribute to the absence of methanogenic archaea, as well as the abundance of aerobic bacteria. In addition, the reduction of sulfate under oxic conditions has been observed (Kieldsen et al., 2004; Fike et al., 2008), which would explain the abundance of sulfate-reducing Deltaproteobacteria in most samples, despite the high concentration of DO in the groundwater.

Methylocella spp. are not associated with the previously known type-II cluster of methanotrophs but are closely related to a non-methanotroph (Dedysh et al., 2005), suggesting different affinities to $\mathrm{CH}_{4}$ and $\mathrm{O}_{2}$ compared to previously known type-II methanotrophs (Amaral and Knowles, 1995). There is no correlation between the methanotrophic community in each sample and the $\mathrm{CH}_{4}$ data reported in Iverach et al. (2015) nor is there any correlation between the composi- tion of methanotrophs and DO in the groundwater (Table S2 in the Supplement).

The sample with the most diverse bacterial community (Sample F, Fig. 4) had the most ${ }^{13} \mathrm{C}$-enriched individual $\delta^{13} \mathrm{C}-\mathrm{CH}_{4}$ relative to regional background (Iverach et al., 2015) (Table S3 in the Supplement). A relatively high abundance $(11 \%)$ of relatives belonging to the Chloroflexi phylum was observed exclusively in this groundwater sample.

\subsection{Absence of anaerobic methane oxidation}

The lack of detection of the $m c r A$ gene not only indicates the absence of methanogens but also suggests the absence of anaerobic methanotrophs (Hallam et al., 2003). Details on the functional genomic link between methanogenic and methanotrophic archaea are discussed comprehensively in Hallam et al. (2003). Additionally, no sequences belonging to ANME-SRB clades were detected in the groundwater samples, indicating the absence of ANME activity. However, members of the phylum Thaumarchaeota dominated the archaeal community in the groundwater (Fig. 4). Thaumarchaeota contains several clusters of environmental sequences representing microorganisms with an unknown energy metabolism (Pester et al., 2011). Members of the Thaumarchaeota encode monooxygenase-like enzymes able to utilise $\mathrm{CH}_{4}$, suggestive of a role in $\mathrm{CH}_{4}$ oxidation (Pester et al., 2011).

Samples $\mathrm{D}$ and $\mathrm{H}$ had $\mathrm{SO}_{4}^{2-}$ concentrations of 55 and $29 \mathrm{mg} \mathrm{L}^{-1}$, respectively. This suggests that the $\mathrm{SO}_{4}^{2-}$ concentration is high enough to support $\mathrm{SO}_{4}^{2-}$ mediated AOM at these sites (Whiticar, 1999). The observed $\left[\mathrm{SO}_{4}^{2-}\right]$ was high enough in these two samples to be able to 
measure the stable isotopes in the $\mathrm{SO}_{4}^{2-}$. This is useful because the isotopes yield a unique signature when $\mathrm{SO}_{4}^{2-}$ reduction is coupled to $\mathrm{CH}_{4}$ oxidation in anaerobic conditions (Antler et al., 2015). However, because there are only two data points (Table $\mathbf{S} 2$ in the Supplement), determining a correlation between $\delta^{34} \mathrm{~S}_{-} \mathrm{SO}_{4}$ and $\delta^{18} \mathrm{O}-\mathrm{SO}_{4}$ is statistically invalid. The highest relative abundance of methanotrophs was found in samples D and H (Fig. 4); however, these methanotrophs are not anaerobic oxidisers and therefore the correlation may not imply causation.

The concentration of $\mathrm{NO}_{3}^{-}$and $\mathrm{NO}_{2}^{-}$in the groundwater was also very low relative to groundwaters with the potential for AOM via denitrification (á Norði and Thamdrup, 2014). Our samples had $\left[\mathrm{NO}_{3}^{-}\right]$ranging from 1.2 to $2.3 \mathrm{mg} \mathrm{L}^{-1}$ and $\left[\mathrm{NO}_{2}^{-}\right]$below $0.05 \mathrm{mgL}^{-1}$ (Table $\mathrm{S} 2$ in the Supplement). Therefore, AOM coupled to denitrification is unlikely to be occurring in the groundwater of the CRAA (á Norði and Thamdrup, 2014).

The $\delta^{13} \mathrm{C}$-DIC data indicate limited ${ }^{13} \mathrm{C}$ depletion as a result of DIC formation during AOM. Segarra et al. (2015) showed that maximum ${ }^{13} \mathrm{C}$ depletion of DIC in the zone of maximum AOM activity $(0-3 \mathrm{~cm})$ was highly dependent upon the isotopic composition of the DIC before biological consumption. However, the difference between maximum ${ }^{13} \mathrm{C}$ depletion of DIC and ${ }^{13} \mathrm{C}$ enrichment often exceeded $10 \%$. As our samples are taken from deep in the aquifer (30 $\mathrm{m}$ or more below the ground surface), and the difference between our most ${ }^{13} \mathrm{C}$-depleted DIC value and the most ${ }^{13} \mathrm{C}$ enriched was only 4\%o (Sample H; Table S1 in the Supplement), it is unlikely that AOM is occurring in the groundwater. Additionally, a previous study of the GAB geochemistry showed that $\delta^{13} \mathrm{C}$-DIC values in this region are in the range of -15 to $-6 \%$ (Herczeg et al., 1991). All of our samples fall within this regional range, and we see no obvious ${ }^{13} \mathrm{C}$ depletion of DIC in the groundwater that can be ascribed to AOM.

Therefore, any oxidation occurring in the groundwater would have been facilitated by the two members of type-II methanotrophs that we identified in the microbial community analysis. Both of the species identified are classified as aerobic $\mathrm{CH}_{4}$ oxidisers, agreeing with our geochemical data that no anaerobic oxidation was occurring. Despite abundant $\mathrm{SO}_{4}^{2-}$ in two sample locations, the absence of anaerobic methanotrophic archaea amongst other geochemical evidence (denitrification processes) suggests that it is unlikely that $\mathrm{AOM}$ is occurring within the aquifer.

The above geochemical and microbiological data place constraints on the active process, gas origin and pathways of migration. Figure 6 presents a conceptual schematic of the processes occurring between the WCM and the CRAA.

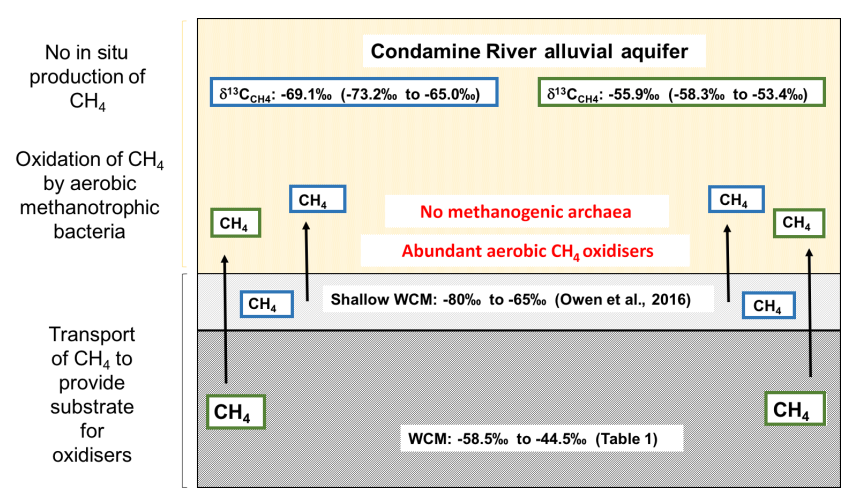

Figure 6. A conceptual schematic of the processes occurring between the WCM and the CRAA.

\section{Conclusion}

We used geochemical and microbiological indicators to explain the occurrence of $\mathrm{CH}_{4}$ in the groundwater of an alluvial aquifer. Microbial community analysis and geochemical data were consistent with a lack of methanogenic archaea and methanogenic activity in the aquifer. What is the original source of the $\mathrm{CH}_{4}$ if not biologically produced in situ? One hypothesis to explain the presence of $\mathrm{CH}_{4}$ despite there being no evidence of methanogenesis is that there is localised upward migration of $\mathrm{CH}_{4}$ from the WCM into the CRAA via natural faults and fractures (Iverach et al., 2015).

Our geochemical data and microbiological community analysis both indicate that AOM is not a major oxidation process occurring in the CRAA. However, the microbiological data suggest the presence of aerobic $\mathrm{CH}_{4}$ oxidisers. Due to the absence of methanogenesis, the oxidation of $\mathrm{CH}_{4}$ (facilitated by the aerobic methanotrophs present in the groundwater) would require a secondary source of $\mathrm{CH}_{4}$. This, coupled with the isotopic signature of the $\mathrm{CH}_{4}$ and the concentration of $\mathrm{SO}_{4}^{2-}$ in the groundwater, suggests that the upwards migration of $\mathrm{CH}_{4}$ from the underlying WCM is the likely source (Fig. 6).

Methane occurs naturally in groundwater, is produced via numerous biological pathways and can migrate through natural geological fractures. Therefore, determination of the source of $\mathrm{CH}_{4}$ using $\left[\mathrm{CH}_{4}\right]$ and $\delta^{13} \mathrm{C}_{-} \mathrm{CH}_{4}$ data alone does not discern all the processes occurring. Our microbiological community analysis showed that there were no methanogens present to produce the $\mathrm{CH}_{4}$ measured in Iverach et al. (2015), and our geochemical analyses supported the absence of methanogenesis in the alluvial aquifer. Similarly, the geochemical and microbiological data revealed that oxidation may not have as large an effect on $\mathrm{CH}_{4}$ due to the low abundance of aerobic oxidisers and the absence of anaerobic archaea.

Therefore, we suggest that the $\mathrm{CH}_{4}$ detected in the CRAA in Iverach et al. (2015) is from the local upward migration of gas from the underlying WCM, either through natural 
faults and fractures, transport along poorly installed well casings, or direct leakage of gas between the WCM and CRAA where the units are in direct contact. A consideration of both geochemical and microbiological analyses is particularly important in this study area because of the immediate proximity of the underlying WCM and the proximity of the study area to CSG production. This research uses biogeochemical constraints on the origin of $\mathrm{CH}_{4}$ in a freshwater aquifer to demonstrate the upward migration of $\mathrm{CH}_{4}$ from an underlying coal seam.

\section{Data availability}

We have provided our data set in the Supplement. All of our findings in this article can be reproduced by the data that we provided, either in the text itself or the Supplement.

In addition, data from Iverach et al. (2015) have been used.

\section{The Supplement related to this article is available online at doi:10.5194/bg-14-215-2017-supplement.}

Author contributions. Experimental conceptualisation and design were carried out by Dioni I. Cendón and Bryce F. J. Kelly. Fieldwork was conducted by Charlotte P. Iverach, Sabrina Beckmann, Dioni I. Cendón and Bryce F. J. Kelly. Geochemical analyses were conducted by Dioni I. Cendón. Microbiological analyses were conducted by Sabrina Beckmann, Charlotte P. Iverach and Mike Manefield. The paper was written by Charlotte P. Iverach and Sabrina Beckmann with input from all authors.

Competing interests. The authors declare that they have no conflict of interest.

Acknowledgement. This research was funded by the Cotton Research and Development Corporation and the National Centre for Groundwater Research and Training (funded by the Australian Research Council and the National Water Commission). The authors thank Stuart Hankin for assistance and expertise in the field and Lisa Williams for reviewing and editing the final paper. In addition, many thanks to the two reviewers, who provided constructive feedback and raised the overall quality of the paper.

Edited by: C. P. Slomp

Reviewed by: M. Currell and one anonymous referee

\section{References}

Amaral, J. A. and Knowles, R.: Growth of methanotrophs in methane and oxygen counter gradients, FEMS Microbiol. Lett., 126, 215-220, 1995.

á Norði, K. and Thamdrup, B.: Nitrate-dependent anaerobic methane oxidation in a freshwater sediment, Geochim. Cosmochim. Ac., 132, 141-150, 2014.

Antler, G.: Sulfur and oxygen isotope tracing of sulfate driven anaerobic methane oxidation in estuarine sediments, Estuar. Coast. Shelf S. 142, 4-11, 2014.

Antler, G., Turchyn, A. V., Herut, B., and Sivan, O.: A unique isotopic fingerprint of sulfate-driven anaerobic oxidation of methane, Geology, 43, 619-622, 2015.

Arrow Energy: Our Operations, available at: http://www. arrowenergy.com.au/our-company/our-projects (last access: 18 May 2016), 2015.

Atkins, M. L., Santos, I. R., and Maher, D. T.: Groundwater methane in a potential coal seam gas extraction region, J. Hydrol. Reg. Stud., 4, 452-471, 2015.

Barker, J. F. and Fritz, P.: The occurrence and origin of methane in some groundwater flow systems, Can. J. Earth Sci., 18, 18021816, 1981.

Baublys, K. A., Hamilton, S. K., Golding, S. D., Vink, S., and Esterle, J.: Microbial controls on the origin and evovlution of coal seam gases and production waters of the Walloon Subgroup; Surat Basin, Australia, Int. J. Coal Geol., 147-148, 85104, 2015.

Bowman, J.: The Methanotrophs: the families Methylococcaceae and Methylocystaceae, in: The Prokaryotes, an evolving Electronic Resource for the Microbiological Community, edited by: Dworkin, M., Falkow, S., Rosenberg, E., Schleifer, K.-H., and Stackebrandt, E., Heidelberg: Springer Science Online, available at: http://www.prokaryotes.com (last access: 19 July 2016), 2000.

Cendón, D. I., Hughes, C. E., Harrison, J. J., Hankin, S. I., Johansen, M. P., Payne, T. E., Wong, H., Rowling, B., Vine, M., Wilsher, K., Guinea, A., and Thiruvoth, S.: Identification of sources and processes in a low-level radioactive waste site adjacent to landfills: groundwater hydrogeochemistry and isotopes, Aust. J. Earth Sci., 62, 123-141, 2015.

Corel Corporation: Corel Painter Education, Version 14.1.0.1105, Ottawa, Canada, 2015.

Craig, H.: Isotopic variations in meteoric waters, Science, 133, 1702-1703, 1961.

Currell, M., Banfield, D., Cartwright, I., and Cendón, D. I.: Geochemical indicators of the origins and evolution of methane in groundwater: Gippsland Basin, Australia, Environ. Sci. Pollut. R., doi:10.1007/s11356-016-7290-0, online first, 2016.

Dafny, E. and Silburn, D. M.: The hydrogeology of the Condamine River Alluvial Aquifer, Australia: a critical assessment, Hydrogeol. J., 22, 705-727, 2014.

Dedysh, S. N., Liesack, W., Khmelenina, V. N., Suzina, N. E., Trotsenko, Y. A., Semrau, J. D., Bares, A. M., Panikov, N. S., and Tiedje, J. M.: Methylocella palustris gen. nov., sp. nov., a new methane-oxidizing acidophilic bacterium from peat bogs, representing a novel subtype of serine-pathway methnaotrophs, Int. J. Syst. Evol. Micr., 50, 955-969, 2000. 
Dedysh, S. N., Knief, C., and Dunfield, P. F.: Methylocella species are facultatively methanotrophic, J. Bacteriol., 187, 4665-4670, 2005.

Dhillon, A., Teske, A., Dillon, J., Stahl, D. A., and Sogin, M. L.: Molecular characterization of sulfate-reducing bacteria in the Guaymas basin, Appl. Environ. Microb., 69, 2765-2772, 2003.

Draper, J. J. and Boreham, C. J.: Geological controls on exploitable coal seam gas distribution in Queensland, APPEA J., 46, 343366, 2006.

Dunfield, P. F., Khmelenina, V. N., Suzina, N. E., Trotsenko, Y. A., and Dedysh, S. N.: Methylocella silvestris sp. nov., a novel methanotrophic bacterium isolated from an acidic forest cambisol, Int. J. Syst. Evol. Micr., 53, 1231-1239, 2003.

Duvert, C., Raiber, M., Owen, D. D. R., Cendón, D. I., BatiotGuilhe, C., and Cox, M. E.: Hydrochemical processes in a shallow coal seam gas aquifer and its overlying stream-alluvial system: implications for recharge and inter-aquifer connectivity, Appl. Geochem., 61, 146-159, 2015.

Ettwig, K. F., Shima, S., van de Pas-Schoonen, K. T., Kahnt, J., Medema, M. H., Op den Camp, H. J. M., Jetten, M. S. M., and Storus, M.: Denitrifying bacteria anaerobically oxidize methane in the absence of Archaea, Environ. Microbiol., 10, 3164-3173, 2008.

Ettwig, K. F., Butler, M. K., Le Paslier, D., Pelletier, E., Mangenot, S., Kuypers, M. M. M., Schreiber, F., Dutilh, B. E., Zedelius, J., de Beer, D., Gloerich, J., Wessels, H. J. C. T., van Alen, T., Luesken, F., Wu, M. L., van de Pas-Schoonen, K. Y., Op den Camp, H. J. M., Janssen-Megens, E. M., Francoijs, K.-J., Stunnenberg, H., Weissenbach, J., Jetten, M. S. M., and Strous, M.: Nitrite-driven anaerobic methane oxidation by oxygenic bacteria, Nature, 464, 543-548, 2010.

Fike, D. A., Gammon, C. L., Ziebis, W., and Orphan, V. J.: Micron-scale mapping of sulfur cycling across the oxycline of a cyanobacterial mat: a paired nanoSIMS and CARD-FISH approach, ISME J., 2, 749-759, 2008.

Fontenot, B. E., Hunt, L. R., Hildenbrand, Z. L., Carlton Jr., D. D., Oka, H., Walton, J. L., Hopkins, D., Osorio, A., Bjorndal, B., $\mathrm{Hu}$, Q. H., and Schug, K. A.: An evaluation of water quality in private drinking water wells near natural gas extraction sites in the Barnett Shale Formation, Environ. Sci. Technol., 47, 1003210040, 2013.

Green-Saxena, A., Dekas, A. E., Daleska, N. F., and Orphan, V. J.: Nitrate-based niche differentiation by distinct sulfate-reducing bacteria involved in the anaerobic oxidation of methane, ISME J., 8, 150-163, 2014.

Hakemian, A. S. and Rosenzweig, A. C.: The biogeochemistry of methane oxidation, Annu. Rev. Biochem., 76, 223-241, 2007.

Hales, B. A., Edwards, C., Ritchie, D. A., Hall, G., Pickup, R. W., and Saunders, J. R.: Isolation and identification of methanogenspecific DNA from blanket bog peat by PCR amplification and sequence analysis, Appl. Environ. Microbiol., 62, 668-675, 1996.

Hallam, S. J., Girguis, P. R., Preston, C. M., Richardson, P. M., and DeLong, E. F.: Identification of methyl coenzyme $M$ reductase A (mcrA) genes associated with methane-oxidising archaea, Appl. Environ. Microbiol., 69, 5483-5491, 2003.

Hamilton, S. K., Esterle, J. S., and Golding, S. D.: Geological interpretation of gas content trends, Walloon Subgroup, eastern Surat
Basin, Queensland, Australia, Int. J. Coal. Geol., 101, 21-35, 2012.

Hamilton, S. K., Golding, S. D., Baublys, K. A., and Esterle, J. S.: Stable isotopic and molecular composition of desorbed coal seam gas from the Walloon Subgroup, eastern Surat Basin, Australia, Int. J. Coal Geol., 122, 21-36, 2014.

Hanson, R. S. and Hanson, T. E.: Methanotrophic bacteria, Microbiol. Rev., 60, 439-471, 1996.

Heilweil, V. M., Grieve, P. L., Hynek, S. A., Brantley, S. L., Solomon, D. K., and Risser, D. W.: Stream measurements locate thermogenic methane fluxes in groundwater discharge in an area of shale-gas development, Environ. Sci. Technol., 49, 40574065, 2015.

Herczeg, A. L., Torgersen, T., Chivas, A. R., and Habermehl, M. A.: Geochemistry of ground waters from the Great Artesian Basin, Aust. J. Hydrol., 126, 225-245, 1991.

Hillier, J. R.: Groundwater connections between the Walloon Coal Measures and the Alluvium of the Condamine River, Central Downs Irrigators Limited, Bribie Island, Queensland, Australia, 2010.

Holmes, A. J., Roslev, P., McDonald, I. R., Iversen, N., Henriksen, K., and Murrell, J. C.: Characterisation of methanotrophic bacterial populations in soils showing atmospheric methane uptake, Appl. Environ. Microbiol., 65, 3312-3318, 1999.

Hu, Y., Feng, D., Liang, Q., Xia, Z., Linying, C., and Chen, D.: Impact of anaerobic oxidation of methane on the geochemical cycle of redox-sensitive elements at cold-seep sites of the northern South China Sea, Deep-Sea Res. Pt. II, 122, 84-94, 2015.

Hughes, C. E. and Crawford, J.: A new precipitation weighted method for determining the meteoric water line for hydrological applications demonstrated using Australian and global GNIP data, J. Hydrol., 464-465, 344-351, 2012.

Huxley, W. J.: Condamine River valley groundwater investigation: the hydrogeology, hydrology and hydrochemistry of the Condamine River valley alluvium, Queensland Water Resources Commission, Brisbane, Australia, 1982.

Illumina: Basespace Sequence Hub, available at: http://basespace. illumina.com, last access: 3 May 2016.

Iverach, C. P., Cendón, D. I., Hankin, S. I., Lowry, D., Fisher, R. E., France, J. L., Baker, A., and Kelly, B. F. J.: Assessing connectivity between an overlying aquifer and a coals seam gas resource using methane isotopes, dissolved organic carbon and tritium, Sci. Rep., 5, 1-11, doi:10.1038/srep15996, 2015.

KCB (Klohn Crippen Berger): Conceptualisation of the Walloon Coal Measures beneath the Condamine Alluvium - Final Report, Dept. of Environment and Resource Management, Toowoomba, Queensland, Australia, 2011.

Kelly, B. F. J. and Merrick, N.: Groundwater Knowledge and Gaps in the Condamine Alliance Area for the Cotton Catchment Communities CRC, UTS - National Centre for Groundwater Management Report, NCGM, 2007.

Kieldsen, K. U., Joulian, C., and Ingvorsen, K.: Oxygen tolerance of sulfate-reducing bacteria in activated sludge, Environ. Sci. Technol., 38, 2038-2043, 2004.

Knittel, K. and Boetius, A.: Anaerobic oxidation of methane: progress with an unknown process, Annu. Rev. Microbiol., 63, 311-334, 2009.

Knittel, K., Boetius, A., Lemke, A., Eilers, H., Lochte, K., Pfannkuche, O., Linke, P., and Amann, R.: Activity, distribution, 
and diversity of sulfate reducers and other bacteria in sediments above gas hydrate (Cascadia margin, Oregon), Geomicrobiol. J., 20, 269-294, 2003.

Knittel, K., Loesekann, T., Boetius, A., Kort, R., and Amann, R.: Diversity and distribution of methanotrophic archaea at cold seeps, Appl. Environ. Microbiol., 71, 467-479, 2005.

Kolb, S., Knief, C., Stubner, S., and Conrad, R.: Quantitative detection of methanotrophs in soil by novel pmoA-targeted real-time PCR assays, Appl. Environ. Microbiol., 69, 2423-2429, 2003.

Kotelnikova, S.: Microbial production and oxidation of methane in deep subsurface, Earth-Sci. Rev., 58, 367-395, 2002.

Kozich, J. J., Westcott, S. L., Baxter, N. T., Highlander, S. K., and Schloss, P. D.: Development of a dual-index sequencing strategy and curation pipeline for analysing amplicon sequence data on the MiSeq Illumina sequencing platform, Appl. Environ. Microbiol., 79, 5112-5120, 2013.

Lane, D. J.: 16S/23S sequencing, in: Nucelic Acid Techniques in Bacterial Systematics, edited by: Stackebrandt, E. and Goodfellow, M., Wiley, Chichester, 205-248, 1991.

Lovley, D. R. and Klug, M. J.: Model for the distribution of sulfate reduction and methanogenesis in freshwater sediments, Geochim. Cosmochim. Ac., 50, 11-18, 1985.

Lueders, T., Manefield, M., and Friedrich, M. W.: Enhanced sensitivity of DNA-and rRNA-based stable isotope probing by fractionation and quantitative analysis of isopycnic centrifugation gradients, Environ. Microbiol., 6, 73-78, 2004.

Maamar, S. B., Aquilina, L., Quaiser, A., Pauwels, H., MichonCoudouel, S., Vergnaud-Ayraud, V., Labasque, T., Roques, C., Abbott, B. W., and Dufresne, A.: Groundwater Isolation Governs Chemistry and Microbial Community Structure along Hydrologic Flowpaths, Fron. Microbiol., 6, 1457, doi:10.3389/fmicb.2015.01457, 2015.

McDonald, I. R., Bodrossy, L., Chen, Y., and Murrell, J. C.: Molecular ecology techniques for the study of aerobic methanotrophs, Appl. Environ. Microbiol., 74, 1305-1315, 2008.

McDonald, L. R., Kenna, E. M., and Murrell, J. C.: Detection of methanotrophic bacteria in environmental samples with the PCR, Appl. Environ. Microbiol., 61, 116-121, 1995.

Meredith, K. T., Han, L. F., Hollins, S. E., Cendón, D. I., Jacobsen, G. E., and Baker, A.: Evolution of chemical and isotopic composition of inorganic carbon in a complex semi-arid zone environment: Consequences for groundwater dating using radiocarbon, Geochim. Cosmochim. Ac., 188, 352-367, 2016.

Moore, T. A.: Coalbed methane: a review, Int. J. Coal Geol., 101, 36-81, 2012.

Moritz, A., Hélie, J. F., Pinti, D. L., Larocque, M., Barnetche, D., Retailleau, S., Lefebvre, R., and Gélinas, Y.: Methane baseline concentrations and sources in shallow aquifers from the shale gas-prone region of the St. Lawrence Lowlands (Quebec, Canada), Environ. Sci. Technol., 49, 4765-4771, 2015.

Murrell, J. C., Gilbert, B., and McDonald, I. R.: Molecular biology and regulation of methane monooxygenase, Arch. Microbiol., 173, 325-332, 2000.

Muyzer, G., Teske, A., Wirsen, C. O., and Jannasch, H. W.: Phylogenetic relationships of Thiomicrospira species and their identification in deep-sea hydrothermal vent samples by denaturing gel electrophoresis if 16S rDNA, Arch. Microbiol., 164, 165-172, 1995.
Papendick, S. L., Downs, K. R., Vo, K. D., Hamilton, S. K., Dawson, G. K. W., Golding, S. D., and Gilcrease, P. C.: Biogenic methane potential for Surat Basin, Queensland coal seams, Int. J. Coal Geol., 88, 123-134, 2011.

Pester, M., Schleper, C., and Wagner, M.: The Thaumarchaeota: an emerging view of their phylogeny and ecophysiology, Current Opinion in Microbiology, 14, 300-306, 2011.

OGIA: Department of Natural Resources and Mines, Queensland Government, Underground Water Impact Report for the Surat Cumulative Management Area, State of Queensland, 2016.

Op den Camp, H. J. M., Islam, T., Stott, M. B., Harhangi, H. R., Hynes, A., Scouten, S., Jetten, M. S. M., Birkeland, N.-K., Pol, A., and Dunfield, P. F.: Environmental, genomic and taxonomic perspectives on methanotrophic Verrucomicrobia, Environ. Microbiol., Rep. 1, 293-306, 2009.

Osborn, S. G., Vengosh, A., Warner, N. R., and Jackson, R. B.: Methane contamination of drinking water accompanying gaswell drilling and hydraulic fracturing, P. Natl. Acad. Sci. USA, 108, 8172-8176, 2011.

Owen, D. D. R. and Cox, M. E.: Hydrochemical evolution within a large alluvial groundwater resource overlying a shallow coal seam gas reservoir, Sci. Total Environ., 523, 233-252, 2015.

Owen, D. D. R., Shouakar-Stash, O., Morgensern, U., and Aravena, R.: Thermodynamic and hydrochemical controls on $\mathrm{CH}_{4}$ in a coal seam gas and overlying alluvial aquifer: new insights into $\mathrm{CH}_{4}$ origins, Sci. Rep., 6, 1-20, 2016.

QGIS 2.8.2 Wien: Statem Toner and Open Street Map licensed under Creative Commons Attribution - ShareAlike 3.0 license (CCBY-SA), 2015.

Quay, P., Stutsman, J., Wilbur, D., Snover, A., Dlugokencky, E., and Brown, T.: The isotopic composition of atmospheric methane, Global Biogeochem. Cy., 13, 445-461, 1999.

QWC (Queensland Water Commission): Underground water impact report: Surat cumulative management area, QWC, Brisbane, Australia, 2012.

Radke, B. M., Ferguson, J., Cresswell, R. G., Ransley, T. R., and Habermehl, M. A.: Hydrochemistry and implied hydrodynamics of the Cadna-owie-Hooray Aquifer Great Artesian Basin, Bureau of Rural Sciences, Canberra, 2000.

Raghoebarsing, A. A., Pol, A., van de Pas-Schoonen, K. T., Smolders, A. J. P., Ettwig, K. F., Rijpstra, W. I. C., Schouten, S., Sinninghe Damasté, J. S., Op den Camp, H. J. M., Jetten, M. S. M., and Strous, M.: A microbial consortium couples anaerobic methane oxidation to denitrification, Nature, 440, 918-921, 2006.

Ransley, T. R. and Smerdon, B. D. (Eds.): Hydrostratigraphy, hydrogeology and system conceptualisation of the Great Artesian Basin, A technical report to the Australian Government from the CSIRO Great Artesian Basin Water Resource Assessment, CSIRO Water for a Healthy Country Flagship, Australia, 2012.

Roy, J. W. and Ryan, M. C.: Effects of unconventional gas development on groundwater: a call for total dissolved gas pressure field measurements, Groundwater, 51, 480-482, 2013.

Schloss, P. D.: mothur, available at: http://www.mothur.org/ (last access: 3 May 2016), 2009.

Schloss, P. D., Westcott, S. L., Ryabin, T., Hall, J. R., Hartmann, M., Hollister, E. B., Kesniewski, R. A., Oakley, B. B., Parks, D. H., Robinson, C. J., Sahl, J. W., Stres, B., Thallinger, G. G., Van Horn, D. J., and Weber, C. F.: Introducing mothur: open-source, 
platform-independent, community-supported software for describing and comparing microbial communities, Appl. Environ. Microbiol., 75, 7537-7541, 2009.

Schoell, M.: The hydrogen and carbon isotopic composition of methane from natural gases of various origins, Geochim. Cosmochim. Ac., 44, 649-661, 1980.

Segarra, K. E. A., Schubotz, F., Samarkin, V., Yoshinaga, M. Y., Hinrichs, K.-U., and Joye, S. B.: High rates of anaerobic methane oxidation in freshwater wetlands reduce potential atmospheric methane emissions, Nat. Commun., 6, 1-8, 2015.

Sela-Adler, M., Herut, B., Bar-Or, I., Antler, G., Eliani-Russak, E., Levy, E., Makovsky, Y., and Sivan, O.: Geochemical evidence for the biogenic methane production and consumption in the shallow sediments of the SE Mediterranean shelf (Israel), Cont. Shelf Res., 101, 117-124, 2015.

SILVA: High Quality Ribosomal RNA Databases, available at: http: //www.arb-silva.de, last access: 10 May 2016.

Sivan, O., Adler, M., Pearson, A., Gelman, F., Bar-Or, I., John, S. G., and Eckhert, W.: Geochemical evidence for iron-mediated anaerobic oxidation of methane, Limnol. Oceanogr., 56, 15361544, 2011.

Stoecker, K., Bendinger, B., Schöning, B., Nielsen, P. H., Nielsen, J. L., Baranyi, C., Toenshoff, E. R., Daims, H., and Wagner, M.: Cohn's Crenothrix is a filamentous methane oxidizer with an unusual methane monooxygenase, P. Natl. Acad. Sci. USA, 103, 2363-2367, 2006.

Stolper, D. A., Sessions, A. L., Ferreira, A. A., Santos Neto, E. V., Schimmelmann, S. S., Valentine, D. L., and Eiler, J. M.: Combined ${ }^{13} \mathrm{C}-\mathrm{D}$ and D-D clumping in methane: Methods and preliminary results, Geochim. Cosmochim. Ac., 126, 169-191, 2014.

Struchtemever, C. G., Elshahed, M. S., Duncan, K. E., and McInerney, M. J.: Evidence for aceticlastic methanogenesis in the presence of sulfate in a gas condensate-contaminated aquifer, Appl. Environ. Microbiol., 71, 5348-5353, 2005.

Timmers, P. H. A., Suarez-Zuluaga, D. A., van Rossem, M., Diender, M., Stams, A. J. M., and Plugge, C. M.: Anaerobic oxidation of methane associated with sulfate reduction in a natural freshwater gas source, ISME J., 10, 1400-1412, 2015.

Valentine, D. L. and Reeburgh, W. S.: New perspectives on anaerobic methane oxidation, Environ. Microbiol., 2, 477-484, 2000.

Vengosh, A., Jackson, R. B., Warner, N., Darrah, T. H., and Kondash, A.: A Critical Review of the Risks to Water Resources from Unconventional Shale Gas Development and Hydraulic Fracturing in the United States, Environ. Sci. Technol., 48, 8334-8348, 2014.

Vetriani, C., Jannash, H. W., MacGregor, B. J., Stahl, D. A., and Reysenbach, A. L.: Population structure and phylogenetic characterisation of marine benthic archaea in deeo-sea sediments, Appl. Environ. Microbiol., 65, 4375-4384, 1999.

Vidic, R. D., Brantley, S. L., Vandenbossche, J. M., Yoxtheimer, D., and Abad, J. D.: Impact of Shale Gas Development on Regional Water Quality, Science, 340, 1235009, doi:10.1126/science.1235009, 2013.
Wagner, M., Roger, A. J., Flax, J. L., Brusseau, G. A., and Stahl, D. A.: Phylogeny of dissimilatory sulfite reductases supports an early origin of sulfate respiration, J. Bacteriol., 180, 2975-2982, 1998.

Wang, D. T., Gruen, D. S., Lollar, B. S., Hinrichs, K.-U., Stewart, L. C., Holden, J. F., Hristov, A. N., Pohlman, J. W., Morrill, P. L., Könneke, M., Delwiche, K. B., Reeves, E. P., Sutcliffe, C. N., Ritter, D. J., Seewald, J. S., McIntosh, J. C., Hemond, H. F., Jubo, M. D., Cardace, D., Hoehler, T. M., and Ono, S.: Nonequilibrium clumped isotope signals in microbial methane, Science, 348, 428-431, 2015.

Ward, C. R. and Kelly, B. F. J.: Background Paper on New South Wales Geology, University of New South Wales, Sydney, Australia, 2007.

Whiticar, M. J.: Carbon and hydrogen isotope systematics of bacterial formation and oxidation of methane, Chem. Geol., 161, 291314, 1999.

Whiticar, M. J. and Faber, E.: Methane oxidation in sediment and water column environments - isotope evidence, Org. Geochem., 10, 759-768, 1986.

Wilkins, D., van Sebille, E., Rintoul, S. R., Lauro, F. M., and Cavicchioli, R.: Advection shapes Southern Ocean microbial assemblages independent of distance and environmental effects, Nat. Commun., 4, 1-7, 2013.

Wilms, R., Sass, H., Koepke, B., Cypionka, H., and Engelen, B.: Methane and sulfate profiles within the subsurface of a tidal flat are reflected by the distribution of sulfate-reducing bacteria and methanogenic archaea, FEMS Microbiol. Ecol., 59, 611-621, 2007.

Wimmer, B., Hrad, M., Huber-Humer, M., Watzinger, A., Wyhlidal, S., and Reichenauer, T. G.: Stable isotope signatures for characterising the biological stability of landfilled municipal solid waste, Waste Manage., 33, 2083-2090, 2013.

Yoshinaga, M. Y., Holler, T., Goldhammer, T., Wegener, G., Pohlman, J. W., Brunner, B., Kuypers, M. M. M., Hinrichs, K. U., and Elvert, M.: Carbon isotope equilibration during sulphatelimited anaerobic oxidation of methane, Nat. Geosci., 7, 190194, 2014.

Zhang, L. and Soeder, D. J.: Modeling of methane migration in shallow aquifers from shale gas well drilling, Groundwater, 54, 345353, 2016.

Zhu, J., Wang, Q., Yuan, M., Tan, G.-Y. A., Sun, F., Wang, C., Wu, W., and Lee, P.-H.: Microbiology and potential applications of aerobic methane oxidation coupled to denitrification (AME-D) process: a review, Water Res., 90, 203-215, 2016. 